\title{
PÉNZÜGYI TERÜLETEN DOLGOZÓ ÉRTÉKESÍTŐK SZEMÉLYISÉGJELLEMZŐI A JÖVEDELEM NAGYSÁGÁNAK TÜKRÉBEN
}

\author{
PERSONAL CHARACTERISTICS OF FINANCIAL SALES ASSOCIATES IN \\ LIGHT OF THEIR REALIZED INCOME
}

A pénzügyi, biztosítási tevékenység nemzetgazdasági ág területén minden a pénzről szól, a szó szoros és annak átvitt értelmében is. Felvetődik a kérdés: léteznek-e, a vizsgálatban használt kérdőívek - az S-CPI kérdőív, a Super-féle munkaérték kérdőív és az Aspirációs kérdőív - által meghatározott 43 személyiségjellemző közül olyan tulajdonságok, melyek a pénzügyi, biztosítási tevékenység nemzetgazdasági ágban dolgozó értékesítők esetében előre jelezhetik az üzletkötők anyagi sikerességét? Az 1000 fős mintán elvégzett kétváltozós logisztikus regresszióelemzés eredményei alapján - ha nem is számottevően, de - javítható az egyes üzletkötők jövedelem szerinti kategorizálása a következő öt személyiségdimenzió figyelembevételével: Dominancia, Státus elérésére való képesség, Önelfogadás, Függetlenség és Egészség. Azaz e személyiségdimenziókban elért magasabb értékek utalhatnak arra, hogy az adott üzletkötő jobban keres, illetve jobban fog keresni a jövőben.

Kulcsszavak: pénzügy, biztosítás, értékesítők, személyiség, jövedelem.

In the finance and insurance sector of the national economy, both figuratively and literally everything is about money. In this research the author considers the issue of whether the personality features of current or potentially hired financial sales associates determined by the respective tests, including the S-CPI questionnaire, Super's Work Values Inventory, and the Aspiration Index questionnaire (43 kinds of personality features), can predict their material success. In sum it can be concluded that according to the results of the two-variable logistic regression (on a sample of 1000 people in the finance sector), the earning-based categorization of the given sales associates can be improved to a certain extent via the consideration of the following five personality trait dimensions: Dominance, Capacity for Status, Self-Acceptance, Independence, and Physical Health. Higher scores achieved in such personal dimension areas can predict the earning capacity of a sales associate in the future.

Keywords: finance, insurance, sales associates, personality, income

\section{Funding/Finanszírozás:}

A szerző a tanulmány elkészítésével összefüggésben nem részesült pályázati vagy intézményi támogatásban. The author did not receive any grant or institutional support in relation with the preparation of the study.

\section{Szerző/Author:}

Dr. Juhász István, egyetemi adjunktus, Eszterházy Károly Katolikus Egyetem, (juhasz.istvan@uni-eszterhazy.hu)

A cikk beérkezett: 2020. 10. 08-án, javítva: 2021. 04. 22-én és 2021. 05. 17-én, elfogadva: 2021. 05. 19-én.

This article was received: 08. 10. 2020, revised: 22. 04. 2021 and 17. 05. 2021, accepted: 19. 05. 2021.

$\mathrm{J}$ elenünkben az egyre gyorsuló gazdasági folyamatok, a globalizáció, de például a koronavírus-járvány okozta körülmények is egyre rugalmasabb alkalmazkodást igényelnek a vállalkozásoktól - a pandémia idején a munkáltatók is eltérő módon kezelték a rendkívüli helyzetet (Széles, Baranyi, \& Csernák, 2020) - legföképpen azok munkavállalóitól. A vállalatok sikerei ugyanis egyre inkább a megfelelő készségekkel, tapasztalattal, tudással, elkötelezettséggel - illetve megfelelő személyiséggel is - rendelkező emberi erőforrásokon múlik (Effron, Gan- dossy, \& Goldsmith, 2003 in Karoliny \& Poór, 2017). De melyek azok a személyiségjellemzők, amelyek predesztinálják a munkavállalók - jelen tanulmány szempontjából pedig egy kiemelt munkavállalói csoport, a pénzügyi, biztosítási tevékenység nemzetgazdasági ág területén dolgozó értékesítők - anyagi sikerességét? Léteznek egyáltalán ilyen tulajdonságok?

A fenti kérdések felvetéséből is látszik, hogy az eladásmenedzsment egyik legfontosabb jövőbeli célja az lesz, hogy az értékesítők személyes szintjére legyenek 
lefordítva a környezet kihívásai, melynek hatásosságát az adott munkavállaó kiválasztása és személyisége is befolyásolja majd (Bauer \& Berács, 2017). Kotler és Keller szerint ,az eladószemélyzet sikerének titka a hatékony kereskedők kiválasztása” ugyanis ,egy felmérés szerint az eladók legjobb 25\%-a hozza a forgalom több mint 52\%-át. Nagy pénzpocsékolás, ha nem megfelelő embereket alkalmazunk" (Kotler \& Keller, 2016). A hatékony üzletkötők kiválasztásának pedig az a legnagyobb dilemmája, hogy „,bár a vállalatok meg tudják mutatni, kik a legjobb értékesítöik, azt nem tudják megmondani, hogy miért dolgoznak ilyen kiválóan. ...Amit tehetnek, az a jelenlegi legjobban és leggyengébben teljesítő értékesítők tesztelése, aztán egy olyan profil megrajzolása, amely vélhetően sikeres az adott vállalat eladási környezetében” (Mitev, 2016, p. 159).

A pénzügyi területen dolgozó tanácsadók személyisége, képessége, attitűdje felértékelődik a tanácsadás és így az üzletkötés minőségében (Veres, 2017). Éppen ezért az üzletkötők kiválasztására „,nagy súlyt kell fektetni. Azok ugyanis, akik nem rendelkeznek a megfelelő személyiségi jellemzőkkel és képességekkel, sokkal nagyobb valószínűséggel frusztrálódnak és hagyják el a vállalatot..." (Mitev, 2016, p. 152). Ezért is kell egy sikeres üzletkötőnek ,a cégét saját személyiségén keresztül" bemutatni (Kovács, 2015, p. 61). „A sikeresség manifesztálhatóságához pedig hozzátartozik, hogy a bérezés könnyen kapcsolható a teljesítményhez" (Bauer \& Mitev, 2016, p. 29).

\section{Értékesítőktől elvárt kompetenciák}

Az alábbiakban az értékesítői kompetenciákra vonatkozó legfontosabb kutatásokat vetem górcső alá. De mi is a kompetencia pontos fogalmi definíciója? Henczi (2007, p. 16) szerint ,a kompetencia a tanulás (tapasztalás, gyakorlás) eredményeként kialakuló személyes erőforrás-képződmények strukturált és együttes rendszere, mely az egyén számára - egy konkrét szellemi és/vagy fizikai (szak)területen - lehetővé teszi a megszerzett ismeretek és személyiségbeli komponensek konstruktív és sikeres alkalmazását." A vállalatok egy része az 1. táblázatban látható kompetenciamodellt használja ügyfélszolgálati munkatársainak és értékesítőinek kiválasztására. Az itt felsorolt kompetenciák közül kell kiválasztani azokat a kulcskompetenciákat, melyek döntő fontosságúak az adott szervezetnél az emberi erőforrások alkalmazása során (Klein \& Kiss, 2016, p. 7).
De vajon mely személyiségjellemzők határozzák meg egy üzletkötő profitabilitását? Goleman szerint számos kiváló teljesítményű eladónál érhető tetten az úgynevezett cél nélküli jelenlét képessége, melynek révén képes teljesen ráhangolódni az ügyfele érzéseire. Jellemzi őket az is, hogy sokkal fontosabb az ügyféllel való jó viszonyuk, mintsem, hogy elveszítsék azok bizalmát egy esetleges gyors üzletkötés érdekében (Goleman, 2007, pp. 118-119). Szintén ehhez hasonló eredményre jut a Fortune Top 500 ipari cégek körében végzett vizsgálat, mely szerint az értékesítők sikeressége leginkább azok becsületességén bizalmat sugárzó egyéniségén - múlik (Ramaswami \& Singh, 2003, pp. 46-66).

Seligman egy igen tanulságos vizsgálatot végzett a MetLife biztosítótársaság üzletkötőinek bevonásával. Kutatási eredményei szerint az optimista beállítottságú üzletkötők a munkába állástól számított első két évükben 37 százalékkal több üzletet kötöttek pesszimista munkatársaikhoz képest. Seligman tanácsára a vállalat felvett olyan pályázókat is, akik - bár az alkalmasságukat vizsgáló teszten elbuktak -, de magas pontszámot értek el az optimizmust vizsgáló kérdőíven. E csoport az első évben 21 - de, ami még meglepőbb az az, hogy - a második évben 57 \%-kal haladta meg pesszimista kollégáik teljesítményét (Goleman, 1995, pp. 137-138). Berne, a tranzakcióanalízis atyja is ír egyfajta kereskedelmi (értékesítői) jó játszmáról, melyet „Örülök, ha segíthetek” néven aposztrofál. Az ilyen ember valamilyen leplezett indítékból, folyton segíteni akar másokon. Az USA-ban ez a játszma adja a „public relations” alapját (Berne, 1984. p.176). Alapvetö elvárás egy üzletkötővel szemben, hogy legyen jó emberismerö, türelmes, szolgálatkész, udvarias, tapintatos és kiváló kapcsolatteremtő. De olyan fontos kompetenciákra is ügyelnie kell felvételük során, mint a rendezettség, megfelelő felkészültség, empátia, segítőkészség, tiszta megjelenés, szakmai müveltség, udvariasság és az aktív problémamegoldás (Durugy, Kollár, \& Madarász, 2016, p. 13). A „,What makes a successful salesperson?” címü tanulmány szerint egy értékesítő legyen: lelkes, energikus, őszinte és élvezze, hogy emberekkel foglalkozhat, arról nem is beszélve, hogy működjön nála a jutalékos rendszer (Plotkin, 1987, p. 56).

Ingram és LaForge (1992, pp. 83-85) szerint egy sikeres üzletkötő személyiségének legfontosabb öt alkotóeleme a következő: én-erő, szóbeli kommunikációs készség, lelkesedés, empátia, belső motiváció (a szerzők az ego dri-

1. táblázat

Kompetenciamodell értékesítők és ügyfélszolgálati dolgozók esetében

\begin{tabular}{|l|l|l|l|}
\hline \multicolumn{1}{|c|}{ Emberi kapcsolatok } & \multicolumn{1}{c|}{ Információkezelés } & \multicolumn{1}{c|}{ Gondosság } & \multicolumn{1}{c|}{ Energia } \\
\hline Kapcsolat az ügyféllel & Ténykeresés & Minőségre törekvés & Ügyfél-orientáció \\
\hline Meggyőzés & Problémamegoldás & Szervezettség & Optimizmus \\
\hline Szóbeli kommunikáció & Üzleti tudatosság & Megbízhatóság & Eredményre törekvés \\
\hline Írásbeli kommunikáció & Szakmai tudás & & Kezdeményezőkészség \\
\hline Csapatmunka & & & \\
\hline
\end{tabular}

Forrás: Klein \& Kiss $(2016$, p. 7) 
ve kifejezést használják, amit magyarul úgy lehetne fordítani, mint például: énhajtóerő vagy én-ösztöntörekvés vö. Carver \& Scheier, 2006, p. 211). Az értékesítőket jellemző legfontosabb jellemzők kiválasztásánál a szerzők a következő kutatások eredményeit összegezték: 1. egy 15.000 vállalatot érint, mintegy 750.000 értékesítőt vizsgáló felmérés (Greenberg \& Greenberg, 1990), 2. egy marketingés értékesítési vezetők körében felvett kutatás (Gaedeke \& Tootelian, 1989), 3. egy 30 évet vizsgáló tanulmány a személyiségjellemzők és az értékesítői sikeresség között (Comer \& Dubinsky, 1985). Egy másik tanulmány szerint (is) azon értékesítők teljesítettek kiemelkedően, akik bensőséges, meghitt hangulatot teremtettek az üzletkötés során és bizalmas információkkal rendelkeztek üzleti partnereikröl (Liu \& Comer, 2007, pp. 565-574). Mulligan vizsgálata (2004, pp. 46-64) pozitív korrelációt mutatott ki az értékesítők érzelmi intelligenciája és a vállalatok éves árbevétele között. Kiemelte továbbá az asszertivitás és az önbecsülés alapvető szükségességét is. Fordított korrelációt talált azonban a stressz kezelése, valamint az impulzivitás kontrollja között (hasonló eredményt hozott egy magyar mintán végzett felmérés is (Juhász, 2019a)). Egy szintén a stressz üzletkötőkre irányuló hatásait vizsgáló kutatás szerint a stresszt jobban kezelő értékesítők hatékonyabb, úgynevezett problémaközpontú megküzdési stratégiát alkalmaznak munkavégzésük során (Nonis \& Sager, 2003, pp. 139-150). Itt, a stresszel összefüggésben kell megjegyezni, hogy e munkakörben a kiégés egyre gyakoribb, melynek oka az is lehet, hogy csaknem annyi interperszonális stressz ér egy üzletkötőt, mint egy kórházi nővért (Kato, 2014, p. 32). (Ez az adat még akkor is elgondolkoztató, ha a vizsgálatot a koronavírus-járvány előtt folytattuk le.) Nagy valószínüséggel ezen eredmények hátterében az értékesítők körében oly gyakran elöforduló érzelmi kimerülés és deperszonalizáció állhat, melyek közvetetten hatással lehetnek a vállalati eredményességre is (Cicala, 2014, p. 33).

Egy, az értékesítők fejlesztésére hangsúlyt helyező tanulmány szerint a kimagasló teljesítményt elérő üz- letkötőknek az átlagtól magasabb érzelmi intelligenciával kell rendelkezniük (Deeter-Schmelz \& Sojka, 2003, pp. 211-220). Ugyanezen szerzők egy másik publikációjukban azt írják, hogy az érzelmi intelligencia - mint a mások és kiemelten a saját érzelmeik helyes értelmezése - olyan kulcskompetencia az értékesítők körében, mely eladási teljesítményüket még inkább növeli (Sojka \& Deeter-Schmelz, 2002, pp. 43-50). Dankó (2009, pp. 58-59) szerint az Amerikai Egyesült Államokban két olyan kiemelkedő alaptulajdonságot találtak, melyekkel egy sikeres értékesítőnek feltétlenül rendelkeznie kell, ezek a rendületlen törekvés az üzlet nyélbeütésére, illetve az empátia. Fontosak még a következő tulajdonságok és személyiségjellemzők: alkalmazkodó képesség a különböző személyiségű és magatartású ügyfelekhez, elismerés utáni vágy, energikusság, kitartás, a problémamegoldás élvezete, rugalmasság, kezdeményezőkészség, tervező és szervezőképesség, átlagosnál magasabb termet (érdekes módon jelen kutatás ezen utóbbi jellemző és az üzleti teljesítmény között nem talált kimutatható összefüggést, holott a kutatás kérdöíve a vizsgálati személyek magasságára is rákérdezett).

Greenberg szintén az empátia fontosságát hangsúlyozza - az énerőn és a motiváción túl -, mint legfontosabb személyiségjegyet, bár megjegyzi, hogy e személyiségjegyek megléte nem jelenti automatikusan a siker zálogát (Greenberg, 2010). Kevésbé pozitív képet fest a beruházási bankok felső vezetéséről egy kutatás, mely szerint a bankok felső vezetése legtöbbször a személyzet legelkötelezettebb és legagresszívabb tagjaiból áll (Lazear, 2006, p. 277). Ford és munkatársai szerint (Ford, Walker, Churchill, \& Hartley, 1988, in Mitev, 2016, pp. 153-155) a pénzügyi szolgáltatások terén dolgozó munkavállalók teljesítménye erős összefüggést mutatott az olyan változókkal, mint amilyen a családi állapot (házastárs foglakozása, családtagok életkora és száma), továbbá a családi háttér (testvérek száma, szülök képzettsége, iskolán kívüli és sporttevékenységek) (2. táblázat).

A személyes jellemzők és az értékesítők teljesítménye között fennálló összefüggés erőssége

\begin{tabular}{|c|c|c|c|}
\hline \multirow{2}{*}{ Teljesítményre ható tényezők } & \multicolumn{3}{|c|}{ A termék típusa } \\
\hline & Ipari javak & Fogyasztói javak & Szolgáltatások (pénzügyi) \\
\hline Személyes múlt, családi háttér & Gyenge & Gyenge & Erös \\
\hline Családi állapot & Gyenge & Mérsékelt & Erős \\
\hline Eladási alkalmasság & Erös & Mérsékelt & Gyenge \\
\hline Dominancia & Gyenge & Gyenge & Mérsékelt \\
\hline Önértékelés & Erős & Mérsékelt & Mérsékelt \\
\hline Prezentációs készségek & Erős & Mérsékelt & Gyenge \\
\hline Interperszonális készségek & Mérsékelt & Mérsékelt & Gyenge \\
\hline
\end{tabular}

Erős: a változó a variancia több mint $9 \%$-át magyarázza meg.

Mérsékelt: a változó a variancia 4-9\%-át magyarázza meg.

Gyenge: a változó a variancia kevesebb, mint 4 \%-át magyarázza meg.

Szolgáltatások: elsősorban egyéneknek nyújtott pénzügyi szolgáltatásokat vizsgáltak (pl. életbiztosítás, bank).

Forrás: Ford et al. (1988, in Mitev, 2016, p. 155) alapján saját szerkesztés 
A tanulás iránt elkötelezett üzletkötők többsége vásárlóorientált magatartást tanúsít melynek kulcsszerepe van az ügyfélkapcsolatok hosszú távú kezelésében (Harris, Mowen, \& Brown, 2005). Más kutatók azt találták, hogy a pontosságnak, mint személyiségjellemzőnek van jelentős szerepe az értékesítők eredményességében. Ezt az eredményességet olyan további tényezők befolyásolhatják, mint a vevőhöz való hasonlóság, illetve az ügyfél iránti empátia (Hall, Ahearne, \& Sujan, 2015). Megint más szerzők az üzletkötők személyes és a vállalati értékek közötti összhangját, vagy éppen annak hiányát teszik felelőssé a sikeres üzletkötés megvalósulásáért (Schrock, Hughes, $\mathrm{Fu}$, Richards, \& Jones, 2016).

A hazai munkavállalók személyiségét vizsgáló publikációk legfontosabb megállapításait a következőkben részletezzük. Magyarországon az alábbi kompetenciaelemek meglétét keresik a potenciális munkavállalók körében a munkaadók: kezdeményezőkészség, proaktivitás, intellektuális képességek, tanulékonyság/tanulási motiváció, flexibilitás, normakövetés, együttmüködés, stressztürés és terhelhetőség (Henczi, 2006). Más hazai szakemberek szerint egy jó értékesítő a következő tulajdonságokkal kell, hogy rendelkezzen: határozottság, nyitottság, céltudatosság, fogékonyság, jó kommunikációs készség, kreativitás, jó kapcsolatteremtő képesség, kitartás, türelem, ambíció és fejlődőképesség (Seregi \& Varga, 2004). „Amennyiben a pénzügyi, biztosítási tevékenység nemzetgazdasági ágban dolgozó értékesítőkre fókuszálunk, akkor megállapítható, hogy az ezen a területen dolgozó értékesítők a szociabilitás és a teljesítményelérés konformizmus útján dimenziókban nyújtanak kimagasló eredményeket” (Juhász, 2019b, p. 184). Motivációjukkal kapcsán megjegyzendő, hogy az „értékesítők motiválásában olyan higiénés tényezőknek kell, hogy nagyobb szerep jusson, mint például a munka biztonsága, a tekintély, a munkakörülmények javítása, esetleg a tanulási, előmeneteli alternatívák tárházának bővítése" (Juhász, 2019c, p. 47). A hazai üzletkötőkkel szemben elvárás a szakmai müveltség, rendezettség, udvariasság, aktív problémamegoldás, tiszta megjelenés, megfelelö felkészültség, segítőkészség, empátia (Durugy, Kollár, \& Madarász, 2016). Az üzletkötők az ,aspirációs-kérdőívben elért eredmények alapján statisztikailag igazolható mértékben a következő életcélok térnek el a standard értékektől: Gazdagság, Hírnév, Imázs, Növekedés, Kapcsolat és Egészség" (Juhász, 2019d, p. 95). Az egyik - fentebb már említett - kompetenciamodell, melyet értékesítők és ügyfélszolgálati dolgozók esetében alkalmaznak többek között a következő kompetenciák meglétére fókuszál: optimizmus, kezdeményezőkészség, ügyfél-orientáció, meggyőzés, szóbeli és írásbeli kommunikáció, csapatmunka, megbízhatóság, problémamegoldás, üzleti tudatosság (Klein \& Kiss, 2016). „A vizsgált, pénzügyi területen dolgozó üzletkötők közül a hippokratészi vérmérséklettípusok kérdöívben elért eredmények alapján legtöbben a Flegmatikus típusba (a teljes minta 42\%-a) tartoznak, ami Eysenck stabil introvertált kategóriájának felel meg" (Juhász, 2019e, p. 58). Egy 2017-ben publikált vizsgálat ered- ményei alapján az értékesítők szerint egy sikeres hazai üzletkötőnek leginkább a következő három tulajdonsággal kell rendelkeznie: az értékesítés és a kapcsolatok élvezete, személyes kapcsolatok építésének képessége, önbizalom, míg a vevők véleménye alapján a kapacitásigények kezelése, a becsületesség és termékismeret megléte elengedhetetlen (Dankó \& Kovács, 2017). „A Belbin-féle csapattagtípus kérdőívben elért eredmények alapján legtöbben a Vállalatépítő típusba (a teljes minta 26\%-a) tartoznak" (Juhász, 2020). A Vállalatépítő típus legfontosabb tulajdonságai a következők: konzervatív, kiszámítható, kötelességtudó (Belbin, 1998, p. 109). A fentebb idézett kutatásokra és azok vizsgálati eredményeire vonatkozóan azonban meg kell jegyezni, hogy kizárólag a megfelelő személyiségjeggyel rendelkező értékesítő kiválasztása és alkalmazása önmagában még korántsem lesz a siker záloga, ha mindehhez nem kapcsolódik motiváló, inspiráló környezet és szervezeti kultúra. Mindezek hiányában egy üzletkötő sem érhet el hosszú távon kimagasló üzleti sikereket (Yeboah, Alfred, Nimsaah, \& Samuel, 2014, p. 45).

\section{Az alkalmazott vizsgálati eszközök}

Globális szinten számos kiválasztási módszert alkalmazhatnak a nemzetközi nagyvállalatok emberi erőforrásokkal való gazdálkodásuk során. E módszerek egyikének a személyiségtesztek alkalmazásának előnyére írható, hogy bizonyos "feltételek betartása mellett a személyiség-kérdőívek használatának nincsenek komoly veszélyei, a belölük nyert információk az alkalmasságvizsgálat legértékesebb, leghasznosabb részei lehetnek” (Juhász, 2019f, p. 73). A nagy nemzetközi vállalatok kiválasztási metodikája többek között az alábbi személyiségmérő eljárásokat, teszteket is alkalmazhatja: MMPI (Minnesota Multiphasic Personality Inventory), MBTI (Meyers-Briggs Type), OPQ (Occupational Personality Questionnaire), BIG 5 (Big Five Inventory), CPI (California Psychological Inventory) (Poór, 2009, p. 261). Ide sorolható továbbá a Super-féle munkaérték kérdőív és az Aspirációs-kérdőív is egyaránt. Mivel jelen kutatás szempontjából az utóbbi három kérdőív releváns, így az alábbiakban ezeket részletesebben mutatjuk be.

\section{A Kaliforniai Pszichológiai Kérdőív rövidített változata}

A Short California Psychological Inventory (továbbiakban S-CPI), magyarul a Kaliforniai Pszichológiai Kérdőív rövidített változata, kezdeményének tekinthető méröeszközt 1948-ban publikálta Harrison Gough, mely a normál személyiség legfontosabb alapdimenzióinak a feltérképezésére szolgál. A vizsgálati személyeknek az S-CPI kitöltése során 300 (igaz-hamis) kérdésre kell választ adniuk, melyek alapján különböző személyiségdimenzióban elért eredményük állapítható meg. A 21 dimenzió csoportosítása a következő módon történik (Oláh, 1985a, p. 17; Oláh, 1985b, pp. 11-12): I. skálacsoport: Az interperszonális hatékonyság, szociális ügyesség, kiegyensúlyozottság és önbizalom mutatói: Dominancia, Státus elérésére való 
képesség, Szociabilitás, Szociális fellépés, Önelfogadás, Jó közérzet, Szorongás. II. skálacsoport: Szocializáltság, szociális érettség, felelősségtudat, kiegyensúlyozottság és a személyiség értékrendszerének a mutatói: Felelősségtudat, Szocializáltság, Önkontroll, Tolerancia, Énerő, Jó benyomáskeltés, Közösségiség. III. skálacsoport: A teljesítmény motivációs hátterének (intrinzik vagy extrinzik) és az intellektuális hatékonyságnak a mutatói: Teljesítményelérés konformizmus útján, Teljesítményelérés függetlenség útján, Intellektuális hatékonyság. IV. skálacsoport: Az érdeklődés irányultságának, a személyiség plaszticitásának, az intellektus jellemzőinek mutatói: Pszichológiai érzék, Empátia, Flexibilitás, Nőiesség.

\section{A Super-féle munkaérték kérdőív}

A kérdöív tizenöt különféle munkaértéket nevez meg, annak érdekében, hogy megállapítható legyen az egyének milyen különböző értékek mentén végzik/végezhetik sikeresebben munkájukat. A kérdőív kitöltése során 45 állítás esetében kellett meghatároznia a vizsgálati személynek, hogy az adott állítás mennyire fontos számára. A kérdőív értelmezési keretéről elmondható, hogy „1-1 értékkör minimálisan 3, maximálisan 15 pontot kaphat. Az értékek rangsorát a pontszámok rangsora adja. Így a legmagasabb pontszámmá jelölt érték a személyre jellemző legerősebb érték, majd az ehhez kapcsolódó értékek azonos ponttal, vagy egy ponttal leszakadva adják az értékkörökről kialakult értékcsoportot. Ez a 15 érték 1/3-a lehet, ezek a vezető, egyben meghatározó értékei a személyiségnek a munkára vonatkozóan" (Budavári-Takács, 2011, p. 15). Az alábbiakban Szilágyitól származó munkaérték elnevezéseket soroljuk fel: (1987, pp. 7-12): Szellemi ösztönzés, Munkateljesítmény, Önérvényesítés, Anyagi ellenszolgáltatás, Altruizmus, Kreativitás, Társas kapcsolatok, Presztízs, Irányítás, vezetés, Változatosság, Esztétikum, Függetlenség, Hierarchia, Fizikai környezet, A munkával kapcsolatos biztonság.

\section{Az Aspirációs-kérdőív}

A hosszú távú célok és aspirációk feltárására szolgáló kérdőívet, az Aspirációs indexet Kasser és Ryan (1996) dolgozta ki, a Deci és Ryan (1985) által megalkotott úgynevezett „öndeterminációs elmélet” folyományaként. Az elmélet kidolgozói az extrinzik és intrinzik motívumokat, úgynevezett aspirációk (életcélok) formájában fogalmaztak meg, melyek legalapvetőbb kategóriái a következők: a gazdagság, hírnév, imázs, növekedés, kapcsolat, társadalom és egészség. Az extrinzik (kívülről ható) aspirációk ezek alapján a gazdagságra és vagyonra, a hírnév elérésére és az imázsra irányuló életcélok, míg az intrinzik (belülről fakadó) aspirációk a személyes növekedésre, a társas kapcsolatok kialakítására és fenntartására, valamint a közösségi és társadalmi célok elérésére irányuló törekvések (V. Komlósi, Rózsa, Bérdi, Móricz, \& Horváth, 2006, pp. 238-239). Az alkalmazott kérdöív 35 kérdésből áll és egy, egytől hétig terjedő Likert-skálán kell a vizsgálati személyeknek fontossági sorrendjük alapján, az egyes aspirációkra vonatkozó állításokat osztályozniuk.

\section{A pénzügyi, biztosítási tevékenység mint önálló nemzetgazdasági ág és jellemzői}

Nemzetközi szinten ,az értékesítési és a marketingpozíciók nyújtják a legmagasabb javadalmazást: a korábbi években a pénzügyi, valamint az értékesítési és marketing funkcionális területek alkalmazottai messze kiemelkedően vezették a bérezési rangsort. Felmérések szerint az értékesítői és marketingpozíciók megtartották vezető helyzetüket. A pénzügyi, közgazdászi és adminisztratív pozíciókban azonban a munkaerö-túlkínálat miatt az itt dolgozók bérelőnye csökkent" (Poór, 2009, p. 355). A fenti gondolatokból kiindulva az alábbiakban szeretném bemutatni, hogy hogyan alakultak az átlagkeresetek a jelen tanulmány szempontjából kiemelt pénzügyi-biztosítási területen.

A pénzügyi, biztosítási tevékenység nemzetgazdasági ág sokak számára leginkább az anyagi biztonság, a jó kereseti lehetőségek, a kulturált munkakörülmények miatt vonzó. A Központi Statisztikai Hivatal honlapján található adatok ezt meg is erősítik. Az alkalmazásban állók havi bruttó átlagkeresete nemzetgazdasági ágak szerinti bontásban és az elmúlt éveket figyelembe véve a pénzügyi, biztosítási tevékenységet végző munkavállalók esetében volt a legmagasabb (3. táblázat). 2020. évben ez átlagosan havi 709 ezer forintot jelentett. A második helyen az információ, kommunikáció (677 ezer forint), a harmadik helyen a villamosenergia-, gáz-, gőzellátás, légkondicionálás tevékenység (652 ezer forint) szerepel. Ugyanezen időszakban a nemzetgazdaság egészét tekintve - közfoglalkoztatottak nélkül - a havi bruttó átlagkereset 415 ezer forint volt (Központi Statisztikai Hivatal, 2021a). Az elmúlt három évre vonatkozó adatok alapján is a pénzügyi, biztosítási tevékenységet folytató és alkalmazásban álló munkavállalók körében voltak a legmagasabbak az átlagkeresetek, melyek folyamatosan emelkedtek is a vizsgált időszakban (1. ábra).

1. ábra

Az alkalmazásban állók havi bruttó átlagkeresete a nemzetgazdaság különböző ágaiban, 2017-2020 között (kerekítve ezer HUF)

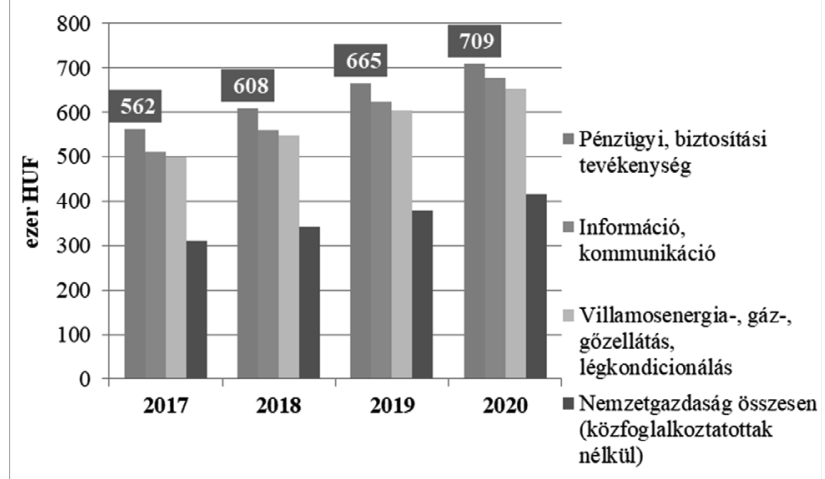

Forrás: Központi Statisztikai Hivatal (2021a) alapján saját szerkesztés

A pénzügyi, biztosítási tevékenység nemzetgazdasági ágban foglalkoztatottak számát nemenként (TEÁOR'08 
alapján) a 2. ábra tartalmazza. A nemzetgazdasági ágak szerinti adatok alapján a pénzügyi, biztosítási tevékenységet végző foglalkoztatottak száma 84351 fő volt 2020-ban, mely nemenként a következő megoszlással bír: nők: 48250 fö, míg a férfiak: 36101 fö. Mindez némi női „dominanciára" utal.

\section{A foglalkoztatottak száma nemzetgazdasági ágak, ágazatok szerint, nemenként - TEÁOR'08 (2014-2020) (kerekítve ezer fő)}

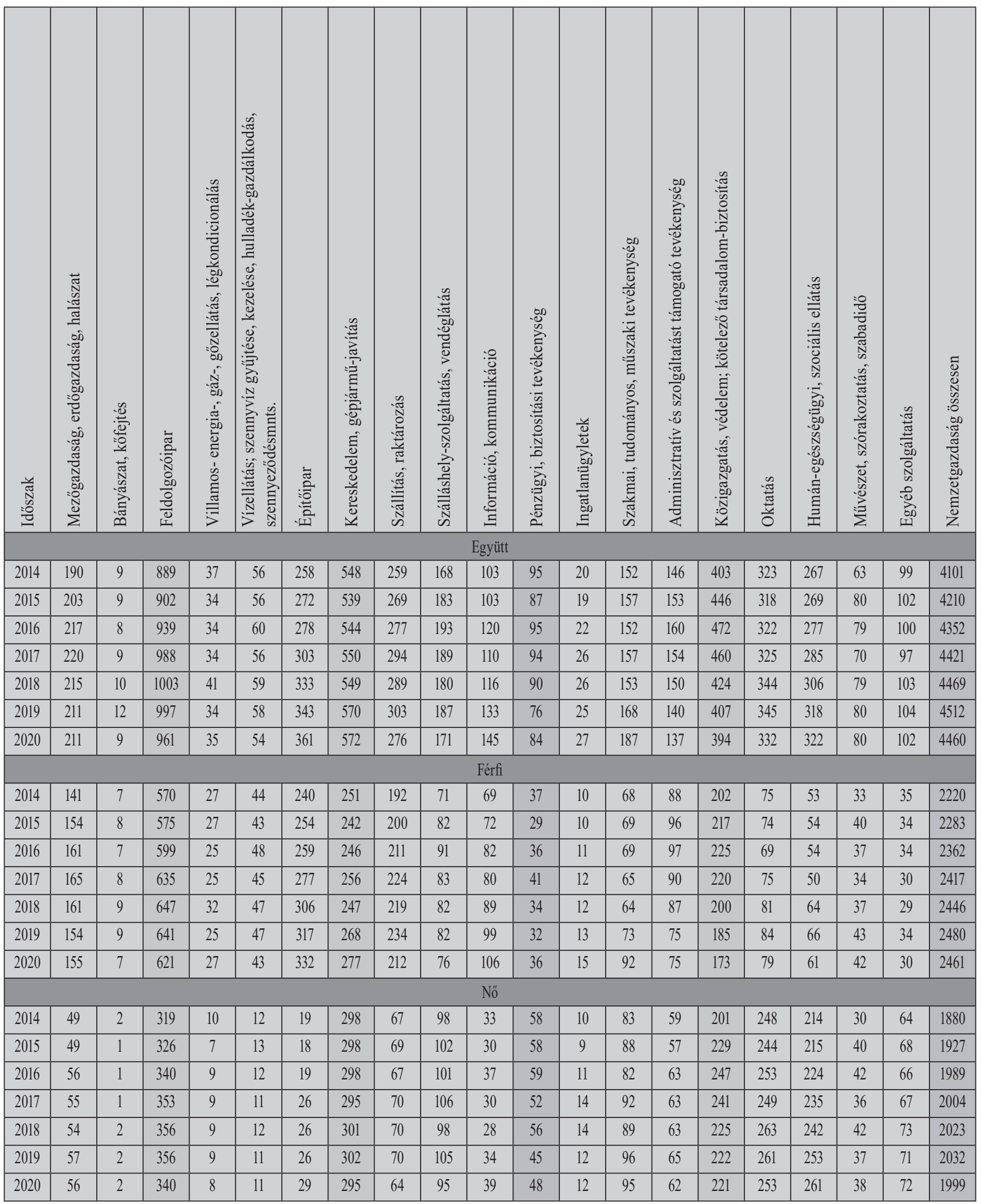

Forrás: Központi Statisztikai Hivatal (2021b) alapján saját szerkesztés 
2. ábra A pénzügyi, biztosítási tevékenység nemzetgazdasági ágban foglalkoztatottak száma nemenként - TEÁOR'08 (2011 - 2020) (kerekítve ezer fő)

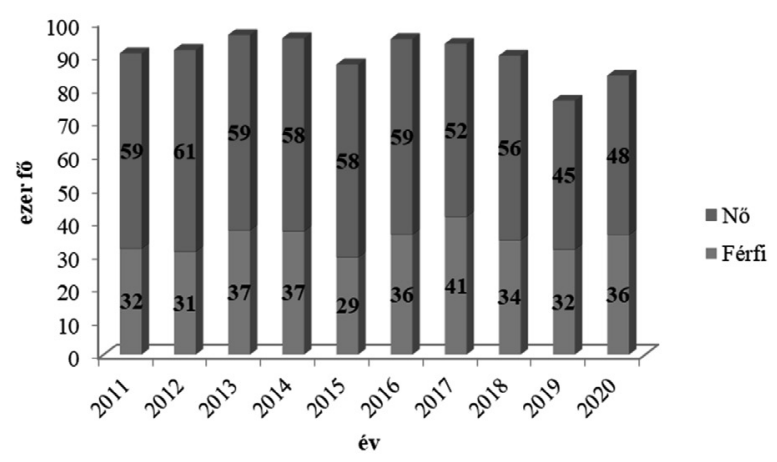

Forrás: Központi Statisztikai Hivatal (2021b) alapján saját szerkesztés

FEOR-számok alapján a Központi Statisztikai Hivatal nem készít munkakörök szerinti statisztikai felméréseket sem év közben, sem év végén. A népszámláláskor kérdeznek rá az ilyen jellegü adatokra a kérdezőbiztosok. Megjegyzendő, hogy az elmúlt évtizedekhez kapcsolódó népszámlálási adatok folyamatos emelkedést mutatnak a pénzügyi, biztosítási tevékenységet végző munkavállalók esetében: 1980-ban 30562, 1990-ben 45524, 2001-ben 69678, 2011-ben pedig 103573 fö dolgozott ezen a területen (Központi Statisztikai Hivatal, 2021c; 2021d). A folyamatos foglalkoztatottilétszám-emelkedés mellett látható, hogy egy cseppet sem elhanyagolható mennyiségű munkavállalót alkalmazó ágról van szó a pénzügyi, biztosítási tevékenység esetében (Juhász, 2019a, p. 46).

\section{A kutatás módszertana: a vizsgálat alanyai, mérés, adatgyüjtés, elemzés}

\section{A vizsgálat alanyai}

Elöljáróban itt kell megjegyezni, hogy a jelen tanulmányhoz kapcsolódó doktori kutatás vizsgálati körülményei, módszertana, valamint a minta jellemzői szükségszerűen megegyeznek más, a doktori kutatáshoz kapcsolódó publikációk vizsgálati körülményeivel és módszertanával, további komponensei azonban nem. A vizsgálat alanyai a jelenleg pénzügyi területen, azon belül is értékesítői munkakörben dolgozó munkavállalók. A bankoknál, biztosító társaságoknál, lakástakarék-pénztáraknál, pénzügyi tanácsadóknál, valamint faktorcégeknél, lízingcégeknél, takarékszövetkezeteknél és tőzsdei vállalatoknál dolgozó foglalkoztatottak alapsokaságából az ügyfelekkel közvetlenül, személyes kontaktusba kerülő értékesítők kerültek a kutatás középpontjába.

\section{Mérés, adatgyűjtés}

A mérés során az alábbiakban felsorolt - zárt és nyitott kérdésekre épülő - részekből álló online kérdőívet töltötték ki a vizsgálati személyek: Alap- és demográfiai adatok, Kaliforniai Pszichológiai Kérdőív rövidített változata, Super-féle munkaérték kérdőív, Aspirációs kérdőív. A vizsgálati alanyok online, az internet segítségével töltötték ki a saját digitalizálású kérdöívet, kiküszöbölve így a papíralapú vizsgálatfelvételnél esetlegesen felmerülő téri és időbeli korlátokat. A kérdésekre adható válaszok többségét úgy alakítottuk ki, hogy a válaszadók egyszerü ,,kattintással”, vagy a legördülő menüből történő szelektálással jelölték meg a rájuk legjellemzőbb választ. Néhány kérdésnél azonban elkerülhetetlen volt a billentyüzet használta, mint például a legmagasabb fokú szakmai végzettség, vagy a munkakör pontos megnevezése (ha nem szerepelt a felsoroltak között). A vizsgálat során intim, személyes jellegü kérdéseket is felvettünk, ezért az egyes kérdésekre adott konkrét válaszokat és azok eredményeit szigorúan a vizsgálati alanyok személyes adataiként, bizalmasan kezeltük. Amennyiben a válaszadók kérték, akkor személyre szabott kiértékelést kaphattak a egyéni vizsgálati eredményeikről. Az eredményeket e-mailben, excel fájlként kapták meg a vizsgálati személyek, melyben az adatokat táblázatok és diagramok formájában rögzítettük. Kiküldtünk továbbá egy 18 oldalas word dokumentumot is, mely az eredmények részletes magyarázatát tartalmazta.

$\mathrm{Az}$ adatgyüjtés legfontosabb ismérvei a következők: a mintavétel a nem véletlen mintavételi eljárások közül annak széles körű felhasználhatósága és a kutatásra vonatkozó jó adaptálhatósága miatt - a hólabda mintavételi eljárással történt. A hólabda mintavételi eljárás lényegéből adódóan a kérdőívet már kitöltő válaszadók is meg lettek kérve (a kérdőív linkjének számukra újbóli elküldésének segítségével), hogy javasolják a kérdőív kitöltését ismertségi körükbe az ugyanehhez a célsokasághoz tartozó potenciális válaszadóknak. Megkerestünk továbbá olyan nagyobb, a pénzügyi, biztosítási tevékenység nemzetgazdasági ághoz kapcsolódó szervezeteket és azok tagjait közvetlen vagy közvetett formában, mint a Magyar Bankszövetség, a Magyar Biztosítók Szövetsége, az Országos Takarékszövetkezeti Szövetség, a Pénzügyi Vállalkozások Országos Egyesülete, a Magyar Lízingszövetség, a Magyar Kereskedelmi és Iparkamara, a Magyar Közgazdasági Társaság.

1656 fő kezdte meg a kérdőív kitöltését. 1069 fő töltötte ki teljes egészében a kérdöívet. 1000 fő eredményei kerültek bele a véglegesített mintába, 69 fö eredményeit különböző okok (pl. nem releváns munkakör, nem releváns gazdasági ág stb.) miatt ki kellett szürni a mintából. 584 fő kérte és kapta meg a kérdőív alapján elért eredményeit e-mailben.

\section{Elemzés}

A begyüjtött adatok elemzése és kiértékelése az excel és az SPSS programok segítségével történt. A statisztikai próbák közül - a hipotézisben foglaltak alátámasztására a leginkább megfelelőnek látszó elemzési módszert, azaz - a kétváltozós logisztikus regresszióelemzést alkalmaztam. Bár indokoltabb lett volna ebben az esetben a rendelkezésre álló módszerek közül a diszkriminanciaelemzést alkalmazni, de ott nem - még több kategorizálás után sem - sikerült nagyjából azonosnak mondható csoportnagyságokat létrehozni a keresetek függvényében. Mivel a diszkriminanciaelemzés meglehetősen robosztus a feltételek teljesülését illetően, így a szakemberek javaslatára 
is (Sajtos \& Mitev, 2007, pp. 332-336) a feltételek tekintetében megengedőbb módszert, a kétváltozós logisztikus regresszióelemzést választottam.

\section{A pénzügyi területen dolgozó értékesítők mintájának demográfiai és munkaügyi jellemzői}

Az alábbiakban szeretném részletezni a pénzügyi területen, értékesítői munkakörben dolgozó munkavállalók 1000 fős mintájának leglényegesebb jellemzőit, demográfiai, munkaügyi és jövedelmi ismérveit. A válaszadók nemek szerinti megoszlásáról elmondható, hogy a nők jelentős „túlsúlyban” vannak $(62,2 \%)$ a férfiakhoz $(37,8 \%)$ képest. Születési idő szerint legtöbben az 1971 és 1980 közötti évtizedből képviseltették magukat, a minta 30,7\%-át adva (3. ábra). A legidősebb kitöltő egy 1933-as szegedi férfi, míg a legfiatalabb kitöltők 1998-as születési idejü nők voltak (egy budapesti és egy jászsági). Születési évszám szerint a legtöbben, összesen 45-en, az 1970-ben születettek közül töltötték ki a kérdőívet.

3. ábra A válaszadók születési idő szerinti csoportosítása (fö)

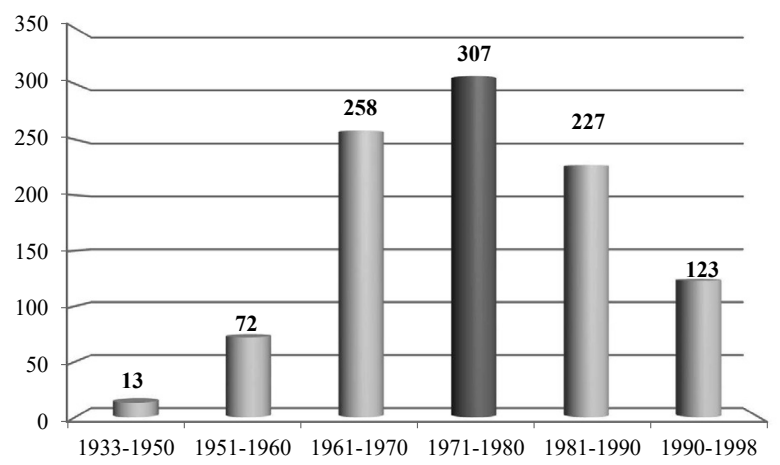

Forrás: saját kutatás alapján, saját szerkesztés

4. ábra A válaszadók lakóhelyének településtípusa szerinti csoportosítása (fő)

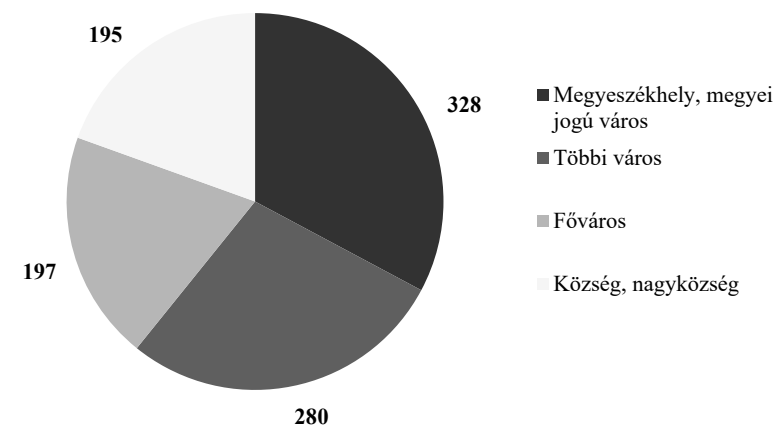

Forrás: saját kutatás alapján, saját szerkesztés

Lakóhelyük szerint a vizsgálatban résztvevőknek a megyeszékhelyen vagy a megyei jogú városokban lakók adták a minta többségét, 32,8\%-át (4. ábra). A 2011. évi népszámlálás adatai alapján a magyar népesség településtípusonkénti megoszlása némiképp eltér a minta ada- taitól (főváros: 17,4\%; megyeszékhely, megyei jogú város: 20,42\%; többi város: 31,65\%; községek, nagyközségek: 30,53\%; (Központi Statisztikai Hivatal, 2021e)). Így a minta nem mondható ebben az értelemben reprezentatívnak, még akkor sem, ha Magyarország minden megyéjéből és Budapestről volt kitöltője a kérdöívnek. Legtöbben - a minta több mint egyötöde - Heves megyéböl (21,2 \%), majd Budapestről (19,7 \%) és Borsod-Abaúj-Zemplén megyéből $(15,4 \%)$ vettek részt a kutatásban.

A legmagasabb iskolai végzettség tekintetében a minta egyharmadát a főiskolai diplomával rendelkező értékesítők adják (5. ábra), öket követik a felsőfokú szakképzésben bizonyítványt szerzett üzletkötők (18,9 \%), majd az egyetemi diplomával rendelkező értékesítők (15,3\%). Valamilyen felsőfokú végzettséggel (felsőfokú szakképzettségtől kezdve a PhD-ig) több mint, a minta kétharmada, 683 fö rendelkezik. A végzettség szerinti hierarchia mindkét végének képviselöi belekerültek a mintába, $\mathrm{PhD}$-fokozattal négyen, míg 8 általános iskolai osztállyal vagy annál kevesebbel hárman rendelkeznek. A legmagasabb iskolai végzettség tekintetében nagyon széles az értékesítői paletta (összesen 473-féle szakmai végzettséget adtak meg a kérdőív kitöltői). A rengeteg és különféle banki, biztosítási, gazdasági, pénzügyi szakmai végzettségek mellett, a teljesség igénye nélkül álljon itt most néhány ,érdekesebb" ezek közül az egyéb végzettségek közül: általános ápoló, autószerelő, edző (C licence), bünügyi szaknyomozó, cukrász, építőmérnök, fogmüves, galambász, gépészmérnök, grafológus, hajóépítő mérnök, hivatásos tiszt, jogász, karosszéria-lakatos, kőmüves, mesterfodrász, női szabó, növényvédelmi agrármérnök, óvodapedagógus, pék, programozó matematikus, pszichológus, rekreációszervező és egészségfejlesztő, rendőrtiszt, speditőr, szakfordító, televíziós újságíró, tolmács, szociológus, tanár, tejtermékgyártó mester, uszodamester, villamosmérnök, vízépítési technikus, zeneiskolai tanár.

\section{5. ábra A válaszadók legmagasabb iskolai végzettség szerinti csoportosítása (fő)}

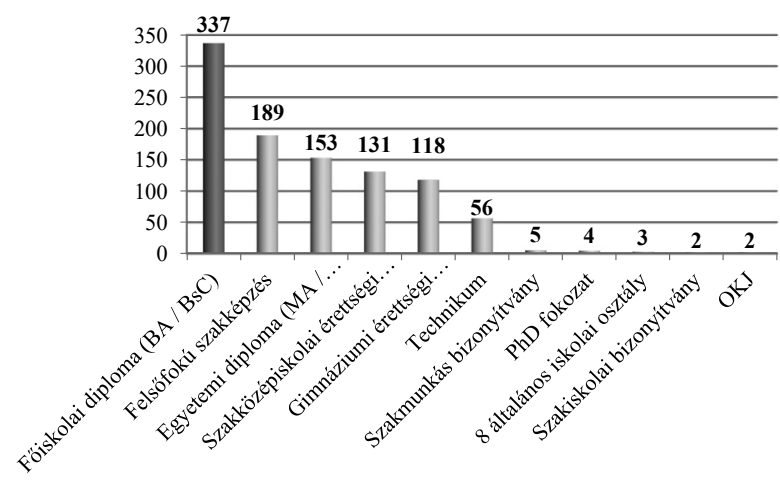

Forrás: saját kutatás alapján, saját szerkesztés

A munkahelyek nemzetgazdasági ágazatok szerinti megoszlása alapján a legtöbb vizsgálati személy bankban dolgozik (6. ábra). Ezt követik a biztosítók, majd a lakástakarék-pénztárak és a pénzügyi tanácsadói irodák munkatársai. A tőzsde, lízing, faktoring és takarékszövetke- 
zeti üzletágak képviselői elenyésző arányban töltötték ki a kérdöívet (a négy terület összesen 5,3\%-át teszi ki a mintának).

\section{6. ábra A válaszadók munkahelyének nemzetgazdasági ágazatok szerinti csoportosítása (fő)}

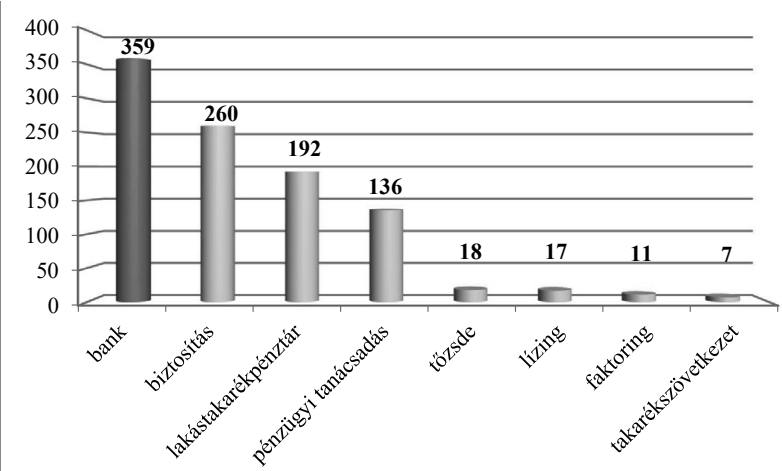

Forrás: saját kutatás alapján, saját szerkesztés

Rendkívül változatos képet mutat az, hogy a válaszadók mennyi ideje dolgoznak a pénzügyi nemzet területén (7. ábra). A legtöbb válaszadó - egyaránt 77-77 fó - kettő, illetve tízéves munkatapasztalattal rendelkezik, míg 76 főnek hároméves pénzügyi, biztosítási tevékenység nemzetgazdasági ágban szerzett munkatapasztalata van. 44 fó kevesebb, mint egy éve dolgozik a pénzügyi, biztosítási tevékenység nemzetgazdasági ág területén, míg legrégebb idő óta - 44 éve - egy Pest megyei nő.

7. ábra A válaszadók pénzügyi, biztosítási tevékenység nemzetgazdasági ágban szerzett munkatapasztalata években (fö)

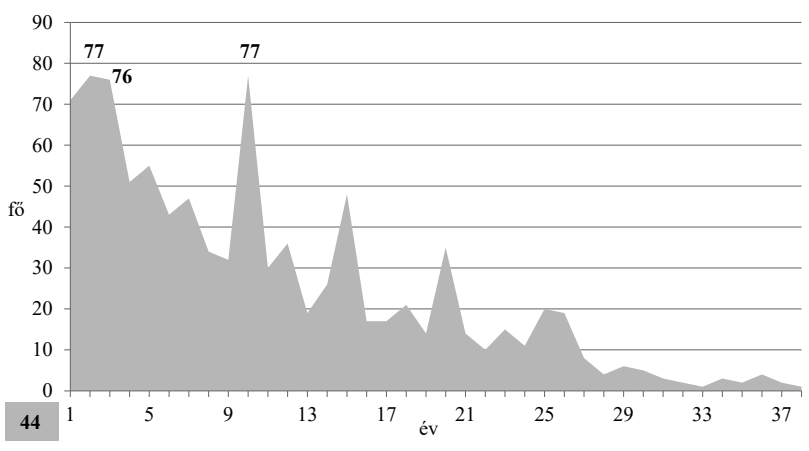

Forrás: saját kutatás alapján, saját szerkesztés

Az éves bruttó jövedelmeket megvizsgálva (8. ábra) a válaszadók közül legtöbben (236 fö) 2 és 2,9 millió forint között keresnek. A második legnépesebb kategóriák esetében egyaránt 183 - 183 fö fizetése esik az 1 - 1,9, valamint a 3 - 3,9 millió forint közötti intervallumokba. Egymillió forintnál kevesebb összeget 66 fö, míg tízmillió forintnál többet összesen 33 fö keres évente. Egyetlen egy fö adott a kérdésnél értelmezhetetlen (,változó” megnevezésü) választ. Az üzletkötők éves bruttó fizetésének átlaga: 4,48 millió forint. Ez abban az esetben igaz, ha a választott fizetési kategóriák maximumát vesszük az egyes értéke- sítők bruttó fizetésének, valamint az egyedüli értelmezhetetlen „,változó” választ adó értékesítő fizetését nem veszszük figyelembe (az összeg megadásának hiányában erre nem is kerülhet sor). Ha az egyetlen harmincmillió forint feletti értéket (123 millió forintot) is kivesszük a mintából az átlag így sem változik számottevően: 4,36 millió forint (Juhász, 2019a, pp. 72-78).

8. ábra A válaszadók éves bruttó jövedelme szerinti csoportosítása (millió forint)

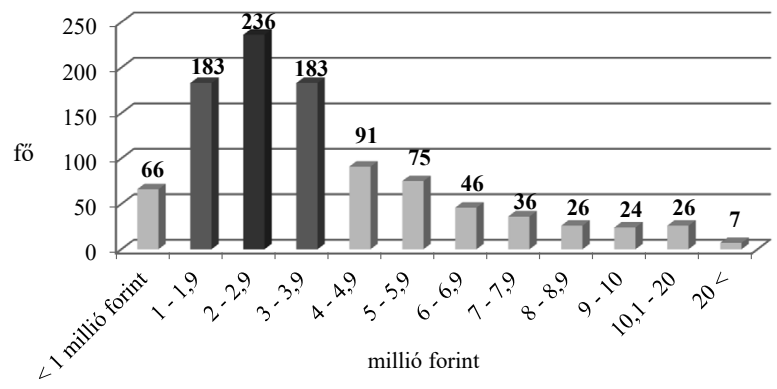

Forrás: saját kutatás alapján, saját szerkesztés

\section{A pénzügyi területen dolgozó értékesítők jövedelme és személyiségjellemzői közötti összefüggések vizsgálata}

\section{Kutatói kérdés, hipotézis}

A pénzügyi, biztosítási tevékenység nemzetgazdasági ág területén minden a pénzről szól, a szó szoros és annak átvitt értelmében is. Felvetődik a kérdés: léteznek-e olyan, a vizsgálatban használt kérdöívek - az S-CPI kérdőív, a Super-féle munkaérték kérdőív és az Aspirációs kérdőív - által meghatározott személyiségjellemzők, melyek a pénzügyi, biztosítási tevékenység nemzetgazdasági ágban dolgozó értékesítők esetében elörejelezhetik az üzletkötők anyagi sikerességét? (Juhász, 2019a, p. 119). A kutatási kérdést mérhetővé téve, az alábbi hipotézist - és az azzal együtt alkalmazni kívánt vizsgálati módszert - fogalmaztam meg: H1) Léteznek olyan, a vizsgálatban használt kérdöivek - az S-CPI kérdöiv, a Super-féle munkaérték kérdöiv és az Aspirációs kérdöiv - által meghatározott személyiségjellemzők, melyek a pénzügyi, biztositási tevékenység nemzetgazdasági ágban dolgozó értékesitők esetében elörejelezhetik az üzletkötök anyagi sikerességét. Hipotézisemet kétváltozós logisztikus regresszióelemzéssel teszteltem (felhasználva a klasszifikációs táblázatok, a Nagelkerke R négyzet mutató, a Cox \& Snell mutató és a Wald-statisztika eredményeit).

\section{A pénzügyi területen dolgozó értékesítők személyiségjellemzői a jövedelem nagyságának tükrében - kutatási eredmények}

A kétváltozós logisztikus regresszióelemzés során a függő változó ebben az esetben bináris, azaz két kimenete lehetséges: az ötmillió forint feletti és az ötmillió forint alatti éves bruttó jövedelemmel rendelkező üzletkötők csoportja. A kutatás során rendelkezésre álló adatok alapján ez az ötmillió forintos értékhatár 
tünt annak az összegnek, amely felett kereső értékesítők már „,sikeresnek” mondhatják magukat (legalábbis anyagi téren). Az elemzésben összesen 999 üzletkötő adatait sikerült bevonni, egy - korábban már említett - üzletkötő ugyanis a nem számszerüsíthető „,változó” megnevezést adta meg az éves bruttó keresetét firtató kérdésre, így ez az adat nem volt értelmezhető. A kutatás alapjául szolgáló minta ötmillió forint alatt és felett kereső üzletkötőinek megoszlását a 4. táblázat mutatja be. Ötmillió forint alatt keres évente a minta 76 százaléka, ütmillió forint felett pedig a minta 24 százaléka. A táblázat 76 százaléka arra utal, hogy ha véletlenszerüen „tippelnénk” arra, hogy egy mintabeli üzletkötő ötmillió forint alatt keres, akkor 76 százalékban lenne igazunk (Sajtos \& Mitev, 2007, p. 356).

A logisztikus regresszió alkalmazása „megkívánja a multikollinearitás tesztelését, illetve azt, hogy az adat- káns eredményeket hozott). Szignifikáns eredményeket az S-CPI kérdőíven belül a Dominancia, a Státus elérésére való képesség és az Önelfogadás, a Super-féle munkaérték kérdőíven belül a Függetlenség, míg az Aspirációs kérdöíven belül az Egészség ért el (bár az Aspirációs kérdőív életcéljai esetében a Kapcsolat is szignifikáns értéket ért el, de az $\operatorname{Exp}(\mathrm{B})$ nem nagyobb, mint egy (ami feltétele az érvényességnek), ezért itt most nem vettük figyelembe). $\mathrm{Az} \operatorname{Exp}(\mathrm{B})$ a táblázat legfontosabb mutatója, ugyanis ez mutatja meg, hogy az egyes értékek mennyivel javítják a becslést. Például a Dominancia 1,105-ös értéke azt jelenti, hogy ha tudjuk egy üzletkötő Dominancia személyiségdimenzióban elért eredményét, az 10,5 százalékkal javítaná annak az esélyét, hogy helyesen kategorizáljuk az adott értékesítőt (ötmillió felett vagy alatt keres) (Sajtos \& Mitev, 2007, p. 359).

A minta ötmillió forint alatt és felett kereső üzletkötőinek megoszlásának klasszifikációs táblázata a logisztikus regresszió elvégzése előtt

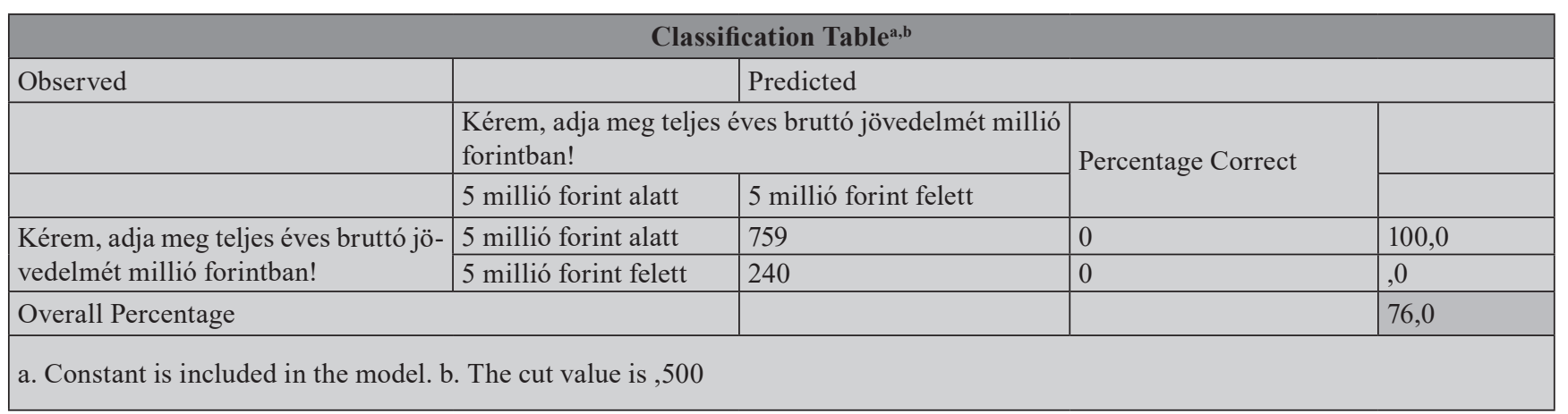

Forrás: saját szerkesztés az SPSS program segítségével

bázis legalább 60 esetet tartalmazzon" (Sajtos \& Mitev, 2007, p. 354). Az adatbázis mindkettő feltételnek megfelel. A 43 személyiségjellemző (mint független változó) kombinációjának hatását a függő változóra kettő mutatószámmal is kiszámítottuk (5. táblázat). A Cox \& Snell R négyzet mutató alapján a 43 változó 16,1 százalékot, míg a Nagelkerke R négyzet mutató alapján 24,2 százalékot magyaráznak. „A Nagelkerke R négyzet a Cox \& Snell mutató módosított változata, és mivel ez utóbbi mindig alulbecsüli a valós értéket, a Nagelkerke-féle mutatóra érdemes hagyatkozni" (Sajtos \& Mitev, 2007, pp. 356-357).

A 43 személyiségjellemző együttes hatásának bemutatására - az ötmillió forint felett és alatt kereső üzletkötők kategorizálásában - terjedelmi okokból itt most nem kerülhet sor. A rendelkezésre álló eredmények egy részét tartalmazó 6 . táblázat azt hivatott bemutatni, hogy a Wald-statisztika alapján (,,amely a béta (B) és a standard hiba hányadosának négyzete") az egyes személyiségdimenziók mennyiben járulnak hozzá a modellhez, amennyiben a Wald-statisztika szignifikáns eredményt hozott az egyes személyiségdimenziók esetében (azaz itt most a táblázatnak csak azon dimenzióit mutatjuk be, ahol a modell szignifi-

\section{A 43 személyiségjellemző (mint független változó) kombinációjának hatása a függő változóra}

\begin{tabular}{|l|l|l|l|}
\hline \multicolumn{4}{|c|}{ Model Summary } \\
\hline Step & $\begin{array}{l}-2 \text { Log likeli- } \\
\text { hood }\end{array}$ & $\begin{array}{l}\text { Cox \& Snell R } \\
\text { Square }\end{array}$ & $\begin{array}{l}\text { Nagelkerke R } \\
\text { Square }\end{array}$ \\
\hline 1 & $925,707^{\text {a }}$ &, 161 &, 242 \\
\hline \multicolumn{3}{|l|}{ a. Estimation terminated at iteration number 5 because param- }
\end{tabular}
eter estimates changed by less than, 001 .

Forrás: saját szerkesztés az SPSS program segítségével

Összeségében megállapítható, hogy a logisztikus regreszszióelemzés eredményei alapján - ha nem is számottevően, de - javítható az egyes üzletkötők jövedelem szerinti kategorizálása a következő öt személyiségdimenzió figyelembevételével: Dominancia, Státus elérésére való képesség, Önelfogadás, Függetlenség és Egészség. Azaz e személyiségdimenziókban elért értékek utalhatnak arra, hogy az adott üzletkötő jobban keres, illetve jobban fog keresni (ha kiválasztásáról még nem döntöttek a vállalat emberi erőforrásokkal foglalkozó szakemberei). A fentiek tükrében a H1) hipotézis teljesül. 
A Wald-statisztika alapján szignifikáns eredményekkel rendelkező személyiségdimenziók és azok Exp(B) értékei

\begin{tabular}{|c|c|c|c|c|c|c|c|c|c|}
\hline \multicolumn{10}{|c|}{ Variables in the Equation } \\
\hline & & \multirow{2}{*}{ B } & \multirow{2}{*}{ S.E. } & \multirow{2}{*}{ Wald } & \multirow{2}{*}{ df } & \multirow{2}{*}{ Sig. } & \multirow{2}{*}{$\begin{array}{l}\operatorname{Exp}(\mathrm{B}) \\
\text { Lower }\end{array}$} & \multicolumn{2}{|c|}{$95 \%$ C.I. for $\operatorname{Exp}(B)$} \\
\hline & & & & & & & & Upper & \\
\hline \multirow{7}{*}{ Step $1^{\mathrm{a}}$} & Dominancia & ,099 &, 039 & 6,514 & 1 &, 011 & 1,105 & 1,023 & 1,192 \\
\hline & Státus elérésére való képesség &, 152 &, 051 & 8,983 & 1 &, 003 & 1,164 & 1,054 & 1,285 \\
\hline & Önelfogadás &, 135 &, 056 & 5,780 & 1 &, 016 & 1,145 & 1,025 & 1,278 \\
\hline & Függetlenség &, 144 &, 068 & 4,429 & 1 &, 035 & 1,155 & 1,010 & 1,321 \\
\hline & Kapcsolat &,- 077 &, 031 & 6,320 & 1 &, 012 & ,926 & ,872 & ,983 \\
\hline & Egészség &, 089 &, 033 & 7,103 & 1 &, 008 & 1,093 & 1,024 & 1,166 \\
\hline & Constant & $-4,359$ & 1,758 & 6,145 & 1 &, 013 & 013 & & \\
\hline
\end{tabular}

a. Variable(s) entered on step 1:

S-CPI kérdőív vizsgált dimenziói: Dominancia, Státus elérésére való képesség, Szociabilitás, Szociális fellépés, Önelfogadás, Jó közérzet, Szorongás, Felelősségtudat, Szocializáltság, Önkontroll, Tolerancia, Énerő, Jó benyomás keltés, Közösségiség, Teljesítményelérés konformizmus útján, Teljesítményelérés függetlenség útján, Intellektuális hatékonyság, Pszichológiai érzék, Empátia, Flexibilitás, Nőiesség.

Super-féle munkaérték kérdőív vizsgált dimenziói: Szellemi ösztönzés, Munkateljesítmény, Önérvényesítés, Anyagi ellenszolgáltatás, Altruizmus, Kreativitás,

Társaskapcsolatok, A munkával kapcsolatos biztonság, Presztízs, Irányítás, Változatosság, Esztétikum, Hierarchia, Függetlenség, Fizikai környezet.

Aspirációs kérdőív vizsgált dimenziói: Gazdagság, Hírnév, Imázs, Növekedés, Kapcsolat, Társadalom, közösség, Egészség.

Forrás: saját szerkesztés az SPSS program segítségével

\section{A kutatás korlátai}

Mint minden kutatásnak, így jelen kutatásnak is vannak korlátai, melyeket az alábbiakban szeretném bemutatni: a pénzügyi, biztosítási tevékenység nemzetgazdasági ágban dolgozó értékesítők, mintegy 1000 fős mintája több szempontból sem reprezentatív. Egy meghatározott szempontok alapján reprezentatívnak bizonyuló újbóli mintavétel még pontosabb eredményeket hozhatna a kutatás kérdését illetően.

A személyiségtesztek prediktív képessége egyes kutatók szerint gyenge, önmagukban kevéssé alkalmazható. Ezért a tesztek alkalmazása mellett javaslom más kiválasztási eszközök például interjúk, értékelő központok, képességtesztek stb. együttes alkalmazását és ezek eredményei alapján meghozni a végső döntést a jelöltek felvételéről, illetve a már vállalatoknál dolgozó üzletkötők kompetenciáinak fejlesztéséröl. Az S-CPI kérdőív a korai személyiségskálák csoportjába tartozik, ebböl kifolyólag dimenziói sem teljesen átgondoltak. Érdemes lett volna egy új, modernebb vizsgálati eszközzel (pl. CAPTain analízissel) lefolytani a vizsgálatot.

A kutatás talált ugyan kapcsolatot a jövedelmek nagysága és a kiemelt személyiségjellemzők között, de azok nem voltak számottevők (más egyéb vizsgálható tényezők, mint például az értékesítő szintje, az értékesítési feladat komplexitása stb. nem állnak rendelkezésre). A kérdőívek felvétele után terjedt el a világban, így Magyarországon is a koronavírus-járvány. Az azóta eltelt időszakban egészen más kompetenciák, személyiségjellemzők kellettek az értékesítők esetében a sikeres üzletkötéshez, így minden bizonnyal egy újbóli kutatás és mintavétel a jelenlegiektől lényegesen eltérő eredményeket hozna a személyiségjellemzők és a keresetek kapcsolatát illetően.

\section{Konklúzió}

Napjainkban meglehetősen kevés kutatás vizsgálja az üzletkötők személyisége és teljesítménye közötti összefüggéseket. Jelen tanulmány ezt a hiányt próbálta meg pótolni a pénzügyi, biztosítási tevékenység nemzetgazdasági ág, mintegy 1000 értékesítőjének bevonásával végzett vizsgálatával. Az üzletkötés terén azok a munkavállalók fognak legjobban teljesíteni, akiknek személyiségjellemzői leginkább megfelelnek a munkakör betöltéséhez szükséges kompetenciáknak, készségeknek, képességeknek. A tanulmány megírásának e kapcsolódó személyiségjellemzők feltárása volt a célja. A kutatás eredményei alapján a vizsgált 43 személyiségjellemző közül az alábbiakban részletesen ismertetett ötnek van hatása az üzleti teljesítményre.

Az S-CPI esetében a következő három jellemzőnek van kiemelt fontossága (az S-CPI kérdőív által vizsgált 21 lehetséges jellemző közül): 1. Dominancia: a skála segítségével megállapítható, hogy a személy hová helyezi magát a dominancia-szubmisszió tengelyen, interperszonális kapcsolataiban törekszik-e domináns szerepre, továbbá a szociális kezdeményezőkészségről és vezetőképességről is fontos információkat kapunk. A magas pontérték azt jelzi, hogy a személy képes közösségek összefogására, szervezésére, együttesek vezetésére, de férfiak esetében azt is jelenti, hogy erőteljes, magabiztos, kiegyensúlyozott, míg nőknél, hogy parancsolgató, agresszív, önkényeskedö. 2. Státus elérésére való képesség: a skála felvilágosítást nyújt arról, hogy a személy rendelkezik-e azokkal a tulajdonságokkal, személyiségadottságokkal, amelyek alapul szolgálnak ahhoz, hogy szociális közösségekben vezető pozícióra tegyen szert. Magas pontérték esetén a skála a fejlődni, előrehaladni, 
kiemelkedni akarás motivációs alapjait, illetve igényét diagnosztizálja, ami férfiak esetében azt jelenti, hogy valaki megfontolt, független, alkalmazkodó, míg nők esetében azt, hogy tiszta logikájú, individualista, széles érdeklődési körủ. 3. Önelfogadás: a skála a képességeivel, személyes értékeivel tisztában lévő, az önismeret és önértékelés magas szintjén álló, függetlenségre törekvő, kialakított szociális szerepével és helyzetével elégedett személyek identifikálását célozza. Magas értéke férfiaknál az őszinte, szókimondó, választékos, míg nőknél a gúnyos, elszánt, igényes tulajdonságokat takarja (Oláh, 1985a, pp. 18-31; Oláh, 1985c, pp. 12-20).

A Super-féle munkaérték kérdőív 15 értéke közül a függetlenségnek van kiemelt szerepe a teljesítményben, melynek definíciója a következő (Szilágyi, 1987, pp. 7-12): Függetlenség: a függetlenség, mint munkaérték, azon munkavállalók számára kardinális jelentőségü, akik a saját módszer alapján történő munkavégzést részesítik előnyben. Ide tartozik az önálló munkavégzés, az autonómia, az aktivitás ellenőrzési foka, a gyors vagy lassú munkatempó megválasztásának lehetősége. A függetlenség értéke sokszor relatív. Befolyásolhatja a társadalmi trend és a szubjektív élmény szerepének jelentősége is. Aki számára ez az érték nagy horderővel bír, annak fontos, hogy saját területén szabadon, önálló döntéseket hozhasson, munkájába másnak ne legyen beleszólása.

Végezetül az Aspirációs kérdőív intrinzik életcéljairól - így a jelen tanulmány eredményei közül kiemelt Egészség aspirációról is - a következök állíthatók: számos vizsgálati eredmény szerint a pénzügyi teljesítmények és sikerek ádáz hajszolása sokkal rosszabb lelki egészséggel jár, mint a közösség iránti elköteleződés. Bár a pénzügyi eredmények elérése is lehet pozitív hatású, de ez „csak” akkor következik be, ha az ennek elérése iránti vágy önmeghatározott, azaz az értékesítő magának az eredménynek az elérését - és nem az érte kapott anyagi javakat - tartja élvezetesnek (Kasser, 2002; Kasser \& Ryan, 1993; Carver \& Baird, 1998 in Carver \& Scheier, 2006, p. 385). Kasser (2002, pp. 11-20) vizsgálati eredményei szerint, azoknak, akiknek életében a pénz meghatározó jelentöségű, sokkal kevesebb vitalitásról - mint, az egészség egyik legfontosabb mérőszámáról -, illetve „öndetermináltságról” továbbá lényegesen magasabb depresszióról tesznek tanúbizonyságot, mint a hírnevet és pénzt kevésbé fontosnak tartó személyek. Carver és Baird (1998, p. 292) kutatási eredményei arra engednek következtetni, hogy csak és kizárólag a pénzügyi sikerre történő törekvés szignifikáns prediktora lehet az alacsonyabb szintü önmegvalósításnak. Az intrinzik típusú ember számára is fontos az elismerés vagy a pénz, mert ha nem érnek el ezek egy bizonyos alapszintet, akkor motivációja megrendül, függetlenül attól, hogy az intrinzik vagy az extrinzik típusba tartozik-e. Egy bizonyos jövedelemszint elérése után az intrinzik típusú ember már magára a munkára - vagy azon túl, akár a minél egészségesebb élet megvalósítására - tud koncentrálni, míg az extrinzik típusú ember számára továbbra is a pénz a kulcsfontosságú tényezö. Az intrinzik típusú embernek is fontos a munkájának anyagi elismerése, de önmagában nem az elismerés elérése a cél, szemben az extrinzik típussal (Pink, 2010, p. 97; Juhász, 2019d, p. 99). A fentebb részletezett vizsgálati eredmények alapján feltártuk, hogy a pénzügyi területen tevékenykedő értékesítők kiválasztásában érdemes alkalmazni a következő kérdőíveket a vállalatok kiválasztási szakembereinek: az S-CPI kérdőív, a Super-féle munkaérték kérdőív és az Aspirációs kérdőív. A kérdőívek összevont eredményeit tekintve pedig a következő személyiségjellemzőkre érdemes nagyobb hangsúlyt helyezni a kiválasztás során, melyek megjelenése lehet az egyik szükséges, de nem elégséges feltétele a jelölt alkalmazásának: Dominancia, Státus elérésére való képesség, Önelfogadás, Függetlenség és Egészség.

\section{Felhasznált irodalom:}

Bauer, A. \& Berács, J. (2017). Marketing. Budapest: Akadémiai Kiadó.

https://doi.org/10.1556/9789634540076

Bauer, A. \& Mitev, A. (2016). Az értékesítővé válás folyamata. Vezetéstudomány, 47(3), 23-56. https://doi.org/10.14267/VEZTUD.2016.03.03

Belbin, M. (1998). A team, avagy az együttmüködö csoport. Budapest: SHL Hungary Kft.

Berne, E. (1984): Emberi játszmák. Budapest: Háttér Kiadó.

Budavári-Takács, I. (2011). A tanácsadási módszerek. Gödöllő: Szent István Egyetem, Gépészmérnöki Kar. http://www.tankonyvtar.hu/hu/tartalom/ tamop412A/2010-0019_A_tanacsadasi_modszerek/ ch02s02.html

Carver, C. S. \& Baird, E. (1998). The American dream revisited: Is it what you want or why you want it that matters? Psychological Science, 9(4), 289-292. https://doi.org/10.1111/1467-9280.00057

Carver, C. S. \& Scheier, M. F. (2006). Személyiségpszichológia. Budapest: Osiris Kiadó.

Cicala, J. E. (2014). The individual and organizational hazards of loneliness on salespeople. Review of Business and Finance Studies, 5(1), 27-36. ftp://ftp. repec.org/opt/ReDIF/RePEc/ibf/rbfstu/rbfs-v5n1-2014/ RBFS-V5N1-2014-3.pdf

Comer, J. M. \& Dubinsky, A. J. (1985). Managing the Successful Sales Force. Lexington, Massachusetts: D. C. Heath and Co.

Dankó, L. (2009). Személyes eladás - a nappali és levelezö tagozatos Marketing szakos MA közgazdász hallgatók számára. Miskolc: Miskolci Egyetem, Marketing Intézet, Miskolc, Pro Marketing Miskolc Egyesület. http://real.mtak.hu/91375/1/4766.pdf

Dankó, L. \& Kovács, P. (2017). Elégedettségfókuszú személyes értékesítés B2B üzleti kapcsolatokban. In Pistkóti I. (Ed.), Marketingkaleidoszkóp (pp. 9-37). Miskolc: Miskolci Egyetem, Gazdaságtudományi Kar, Marketing és Turizmus Intézet. http://midra.unimiskolc.hu/document/30310/26310.pdf

Deci, E. L. \& Ryan, R. M. (1985). Intrinsic motivation and self-determination in human behaviour. New York: Plenum. 
Deeter-Schmelz, D. R. \& Sojka, J. Z. (2003). Developing effective salespeople: exploring the link between emotional intelligence and sales performance. International Journal of Organizational Analysis, 11(3), 211-220.

https://doi.org/10.1108/eb028972

Durugy, A., Kollár, P. \& Madarász, I. (2016). Eladói kompetenciák mérése próbavásárlással. Vezetéstudomány, 47(2), 12-18. http://unipub.lib.unicorvinus.hu/2275/1/VT 2016n2p12.pdf

Effron, M., Gandossy, R. \& Goldsmith, M. (2003). Managing Human Resources in the 21st Century. Hoboken: Wiley.

Ford, N., M., Walker, O. C. Jr., Churchill, G. A. \& Hartley, S. W. (1988). Selecting Successful Salespeople: A Meta-Analysis of Biographical and Psychological Selection Criteria. In Houston, M. J. (Ed.), Review of Marketing (pp. 90-131). Chicago: American Marketing Association.

Gaedeke, R. M. \& Tootelian, D. H. (1989). Employers Rate Enthusiasm and Communication as Top Job Skills. Marketing News, 27 March, 14.

Goleman, D. (1995). Érzelmi intelligencia. Budapest: Háttér Kiadó.

Goleman, D. (2007). Társas intelligencia - Az emberi kapcsolatok új tudománya. Budapest: Libri Kiadó.

Greenberg, H. M. \& Greenberg, J. (1990). What It Takes to Succeed in Sales. Homewood: Dow-Jones Irwin.

Greenberg, H. M. (2010). The Personality of a Top Salesperson [online]. Precast Magazines, May. https://precast.org/2010/05/the-personality-of-a-topsalesperson/

Hall, Z. R., Ahearne, M. \& Sujan, H. (2015). The Importance of Starting Right: The Influence of Accurate Intuition on Performance in SalespersonCustomer Interactions. Journal of Marketing, 79(3), 91-109. https://doi.org/10.1509/jm.13.0505

Harris, E. G., Mowen, J. C. \& Brown, T. J. (2005). Reexamining Salesperson Goal Orientations: Personality Influencers, Customer Orientation, and Work Satisfaction. Journal of the Academy of Marketing Science, 33(1), 19-35. https://doi.org/10.1177/0092070304267927

Henczi, L. (2006). Kompetenciák. In Dara P., Henczi L. \& Szetei T. (Eds.), Állásvadászat és karriertervezés Gyakorlati fortélyok és munkaerö-piaci technikák nem csak pályakezdöknek (pp. 24-34). Budapest: Perfekt Gazdasági Tanácsadó, Oktató és Kiadó Zrt.

Henczi, L. (2007). Kompetenciafelfogások az Európai Unióban. In Henczi L. \& Zöllei K. (Eds.), Kompetenciamenedzsment (pp. 233-267). Budapest: Perfekt Gazdasági Tanácsadó, Oktató és Kiadó Zrt.

Ingram, T. N. \& LaForge, R. W. (1992). Sales Management: Analysis and Decision Making. Fort Worth: The Dryden Press.

Juhász, I. (2019a). A versenyszféra pszichológiai elvárásai a jelenkor üzletkötőivel szemben - különös tekintettel a pénzügyi, biztositási tevékenység nemzetgazdasági ágra (PhD-dolgozat). Miskolc: Miskolci Egyetem, Vállalkozáselmélet és Gyakorlat Doktori Iskola.

https://doi.org/10.14750/ME.2019.024

Juhász, I. (2019b). Pénzügyi területen dolgozó értékesítők személyiségvizsgálata. Pénzügyi Szemle, 64(2), 175190. https://www.penzugyiszemle.hu/upload/documents/juhaszi-2019-2-mpdf_20190704135952_17.pdf

Juhász, I. (2019c). Értékesítői motivációk - Különös tekintettel a pénzügyi, biztosítási tevékenység nemzetgazdasági ágra. Vezetéstudomány, 50(7-8), 3948.

https://doi.org/10.14267/VEZTUD.2019.07.04

Juhász, I. (2019d). Pénzügyi területen dolgozó értékesítők aspirációinak vizsgálata. Marketing \& Menedzsment, 53(2), 95-107.

https://doi.org/10.15170/MM.2019.53.02.08

Juhász, I. (2019e). Értékesítők hippokratészi vérmérséklet típusa a pénzügyi, biztosítási tevékenység nemzetgazdasági ágban. In Karlovitz J. T. (Eds.), VII. IRI Társadalomtudományi Konferencia (pp. 52-59). Párkány: International Research Institute s.r.o.

Juhász, I. (2019f). Pályaalkalmassági vizsgálatok és alkalmazásuk az emberi erőforrások kiválasztásában - különös tekintettel a személyiségtesztekre. Munkaügyi Szemle, 62(5), 65-74. https://drive.google. com/file/d/12q4uczyXhaCyUtbcEgdd1GCSJkJsWB $8 \mathrm{~b} /$ view

Juhász, I. (2020). Pénzügyi területen dolgozó értékesítők a csapattagtípus kérdöív tükrében. Marketing \& Menedzsment, 54(4), 77-88.

https://doi.org/10.15170/MM.2020.54.04.06

Karoliny, M. \& Poór, J. (2017). Bevezetés. In Karoliny M. \& Poór J. (Eds.), Emberi erőforrás menedzsment kézikönyv - Rendszerek és alkalmazások (pp. 17-22). Budapest: Wolters Kluwer Hungary Kft.

Kasser, T. \& Ryan, R. M. (1993). A dark side of the American dream: Correlates of financial success as a central life aspiration. Journal of Personality and Social Psychology, 65(2), 410-422. https://doi.org/10.1037/0022-3514.65.2.410

Kasser, T. \& Ryan, R. M. (1996). Further examining the American dream: Differential correlates of intrinsic and extrinsic goals. Personality and Social Psychology Bulletin, 22(3), 280-287. https://doi.org/10.1177/0146167296223006

Kasser, T. (2002). The high price of materialism. Cambridge: The MIT Press.

Kato, T. (2014). Coping with interpersonal stress and psychological distress at work: comparison of hospital nursing staff and salespeople. Psychology Research and Behaviour Management, (7), 31-36. https://doi.org/10.2147/PRBM.S57030

Klein, S. \& Kiss, J. (2016). Az értékesitök értéke. Budapest: SHL. http://www.shl.hu/dokumentumtar

Kotler, P. \& Keller, K. L. (2016). Marketingmenedzsment. Budapest: Akadémiai Kiadó. https://doi.org/10.1556/9789630597784

Kovács, Á. L. (2015). Hatásvadászok. Figyelö, 59(14), 6061. 
Központi Statisztikai Hivatal (2021a). Az alkalmazásban állók havi bruttó átlagkeresete a nemzetgazdaságban. Budapest: KSH. http://www.ksh.hu/docs/hun/xstadat/ xstadat_evkozi/e_qli007a.html?back=/stadat_ker

Központi Statisztikai Hivatal (2021b). A foglalkoztatottak száma nemzetgazdasági ágak, ágazatok szerint, nemenként - TEÁOR'08 (2008 -). Budapest: KSH. https://www.ksh.hu/docs/hun/xstadat/xstadat_eves/i_ qlf005a.html

Központi Statisztikai Hivatal (2021c). Népszámlálás 2001 - Foglalkozási és napi ingázási adatok. Budapest: KSH. http://www.nepszamlalas2001.hu/hun/kotetek/07/tablak01.html

Központi Statisztikai Hivatal (2021d). Népszámlálás 2011 - Foglalkoztatás, munkanélküliség, ingázás. Budapest: KSH. http://www.ksh.hu/nepszamlalas/ tablak_foglalkoztatas

Központi Statisztikai Hivatal (2021e). Népszámlálás 2011 - Demográfiai adatok - Népesség számának alakulása, népsürüség, népszaporodás településenként. Budapest: KSH. http://www.ksh.hu/nepszamlalas/tablak_demografia

Lazear, E. P. (2006). A humán erőforrások közgazdaságtana vállalati vezetők részére. Budapest: Nemzeti Tankönyvkiadó Zrt.

Liu, S. S. \& Comer, L. B. (2007). Salespeople as information gatherers: Associated success factors. Industrial Marketing Management, 36(5), 565-574. https://doi.org/10.1016/j.indmarman.2006.02.006

Mitev, A. Z. (2016). Toborzás és kiválasztás. In Bauer A. \& Mitev A. Z. (Eds.), Eladásmenedzsment (pp. 151166). Budapest: Akadémiai Kiadó. https://doi.org/10.1556/9789630597876

Mulligan, R. D. (2004). Self-assessment of social and emotional competencies of floor covering salespeople and its correlation with sales performance [Dissertation Abstracts]. The Sciences and Engineering, 64(9-B), 2004, 4664.

Nonis, S. A. \& Sager, J. K. (2003). Coping strategy profiles used by salespeople: Their relationships with personal characteristics and work outcomes. Journal of Personal Selling \& Sales Management, 23(2), 139-150. https://doi.org/10.1080/08853134.2003.10748994

Oláh, A. (1985a). Pszichológiai tanácsadás a pályaválasztásban - A California Psychological Inventory (CPI) röviditett változatának ismertetése. Budapest: Országos Pedagógiai Intézet.

Oláh, A. (1985b). A Kaliforniai Pszichológiai Kérdőív hazai alkalmazásával kapcsolatos tapasztalatok. In Hunyady Gy. (Eds.), Pszichológiai Tanulmányok XVI. (pp. 53-101). Budapest: Akadémiai Kiadó.

Oláh, A. (1985c). A Kaliforniai Pszichológiai Kérdöiv (California Psychological Inventory - CPI) tesztkönyve. Budapest: Munkaügyi Kutatóintézet.

Pink, D. H. (2010). Motiváció 3.0 - Ösztönzés másképp. Budapest: HVG Kiadó Zrt.
Plotkin, H. M. (1987). What makes a Successful Salesperson? Training and Development Journal, 41(9), 54-56.

Poór, J. (2009). Nemzetközi emberi erőforrás menedzsment. Budapest: CompLex Kiadó Jogi és Üzleti Tartalomszolgáltató Kft.

Ramaswami, S. N. \& Singh, J. (2003). Antecedents and consequences of merit pay fairness for industrial salespeople. Journal of Marketing, 67(4), 46-66. https://doi.org/10.1509/jmkg.67.4.46.18690

Sajtos, L. \& Mitev, A. (2007). SPSS kutatási és adatelemzési kézikönyv. Budapest: Alinea Kiadó.

Schrock, W. A., Hughes, D. E., Fu, F. Q., Richards, K. A. \& Jones, E. (2016). Better together: Trait competitiveness and competitive psychological climate as antecedents of salesperson organizational commitment and sales performance. Marketing Letters, 27(2), 351-360. https://doi.org/10.1007/s11002-014-9329-7

Seregi, Gy. \& Varga, G. (2004). Kapcsolatokat épít a jó értékesítő - Pszichológiai tesztek segítségével tárják fel a személyiségjegyeket. Világgazdaság, 2004. augusztus13. https://www.vg.hu/cegvilag/2004/08/ kapcsolatokat-epit-a-jo-ertekesito

Sojka, J. Z. \& Deeter-Schmelz, D. R. (2002). Enhancing the emotional intelligence of salespeople. Mid-American Journal of Business, 17(1), 43-50. https://doi.org/10.1108/19355181200200004

Széles, Zs., Baranyi, A. \& Csernák, J. (2020). A munkavégzés körülményeinek megváltozása a pandémia idején egy primer kutatás tükrében. In Kovács, T., \& Szóka, K. (Eds.), XIV. Soproni Pénzügyi Napok: „Gazdaságvédelem és pénzügyi kiutak" pénzügyi, adózási és számviteli szakmai és tudományos konferencia. Konferenciakötet (pp. 171-186). Sopron, Magyarország: A Soproni Felsőoktatásért Alapítvány. http://publicatio.unisopron.hu/1971/1/SPN_2020_Konfkozl-171-186Szeles-Baranyi-Csernak.pdf

Szilágyi, K. (1987). A Super-féle munkaérték kérdőiv. Budapest: Munkaügyi Kutatóintézet, Munkalélektani Koordináló Tanács.

V. Komlósi A., Rózsa S., Bérdi M., Móricz É. \& Horváth D. (2006). Az aspirációs index hazai alkalmazásával szerzett tapasztalatok. Magyar Pszichológiai Szemle, 61(2), 237-250.

https://doi.org/10.1556/Mental.7.2006.3.2

Veres, Z. (2017). A szolgáltatásmarketing alapkönyve. Budapest: Akadémiai Kiadó. https://doi.org/10.1556/9789630597395

Yeboah, A., Alfred, O., Nimsaah, W. K. \& Samuel, O. (2014). The Relationship between Personality Traits and Sales Force Performance: A Case Study of Eden Micro Finance. British Journal of Economics, Finance and Management Sciences, 9(1), 34-47. https://www. ajournal.co.uk/EFpdfs/EFvolume9(1)/EFVol.9\%20 (1)\%20Article\%204.pdf 